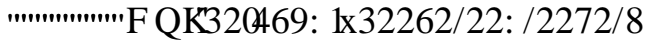

\title{
FACTORS DETERMINING VESSEL SAFETY ASSESSMENT IN OPERATION
}

\section{CZYNNIKI DETERMINUJĄCE OCENE BEZPIECZEŃSTWA STATKU W TRAKCIE EKSPLOATACJI}

\author{
Jarosław Soliwoda \\ Gdynia Maritime University \\ ul. Morska 81-87 \\ 81-225 Gdynia \\ jsoliwoda@wp.pl
}

\begin{abstract}
Approval of higher risk level causes accidents during vessel operation. Binding rules of vessel safety assessment and risk level strictly adhered to regulations do not prevent crew from conscious breaking them. The analysis of reasons of higher risk level acceptance will be presented in this article. The methods of risk analysis will be described in reference to safety vessel operation rules breaking.
\end{abstract}

Keywords: safety assessment, vessel safety, risk assessment, vessel operation

Streszczenie: W czasie eksploatacji statków dochodzi do wypadków, których przyczyną jest akceptowanie wyższego poziomu ryzyka. Pomimo obowiązujących przepisów dotyczących stanu bezpieczeństwa statku i rygorystycznego przestrzegania granicznych parametrów ryzyka dochodzi do świadomego ich łamania. W artykule będzie przedstawiona analiza przyczyn akceptacji przez załogę statku wyższego poziomu ryzyka. Opisane zostaną metody analizy ryzyka w odniesieniu przekraczania ustalonych granic bezpiecznej eksploatacji statku.

Slowa kluczowe: ocena bezpieczeństwa, bezpieczeństwo statku, ocena ryzyka, eksploatacja statku 


\section{FACTORS DETERMINING VESSEL SAFETY ASSESSMENT IN OPERATION}

\section{Introduction}

For many ages of vessels operation, methods of vessel safety use on required level had been worked out. The base method providing vessels safety were legal rules describing ways and forms proper use. Historically these rules were prepared by Classification Societies which provide technical condition assessment service.

Since half on twenty century rules concerning vessel technical condition, crew knowledge and operational action proving vessel safety are have been by International Maritime Organisation [6].

Present vessel safety binding rules assume standardisation of crew members. This standardisation includes physical and psychological aspects of human. However, difference in knowledge experience and culture are not considerate. It causes a lot of accidents not predicted in existing safety systems.

That safety condition is accepted due to economical reasons. Vessels should carry the most quantity of cargo as fast as possible and earn much as fast as possible. Losses on given levels are accepted by insurance companies.

\section{Vessel safety}

Vessel is a complex system working in variable operational conditions. Diversity of carried cargoes, loading operations in different harbours and variation of meteorological conditions make the vessel as an object with varying safety factor.

Vessel safety can be analysed as bi-component process consist of:

- Theoretical safety - assumed safety, which measure is a risk function analysed in long time period with reference to existing system parameters,

- Real safety - achieved safety in operation, which measure is a risk function analysed with reference to actual vessel condition. 


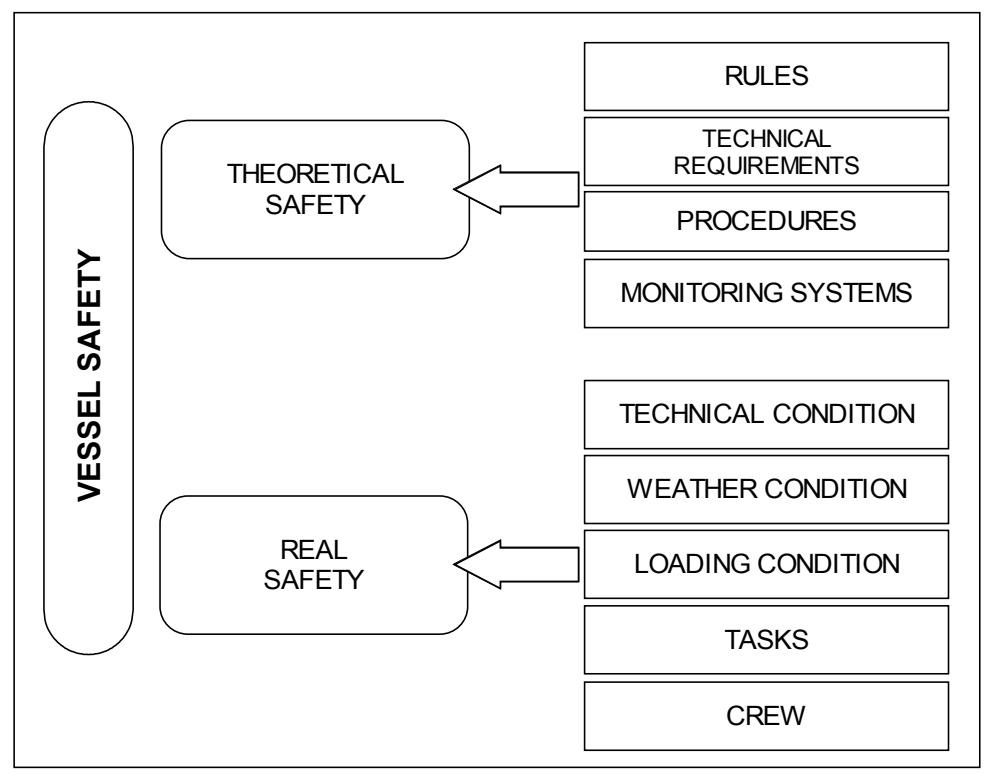

Fig. 1. Vessel safety

The measure of vessel safety is a risk defined as a function of threats and consequences relating to theoretical and actual risk.

$$
R=f\left(P_{A}, P_{C}\right)
$$

Where $P_{A}$ is the probability of threat or failure and $P_{C}$ is the probability of consequences in appropriate category.

Vessel failure reasons are divided into three base groups: hydrometeorological conditions, operator's faults, material wear out and fatigue. Risk function values are calculated for standard threats, which are recorded after accident [4].

The obtained in this way information will be unreliable, it cause the risk value is false. Vessel safety assessment based on standard threat (accident) values is impractical to use by crew. 


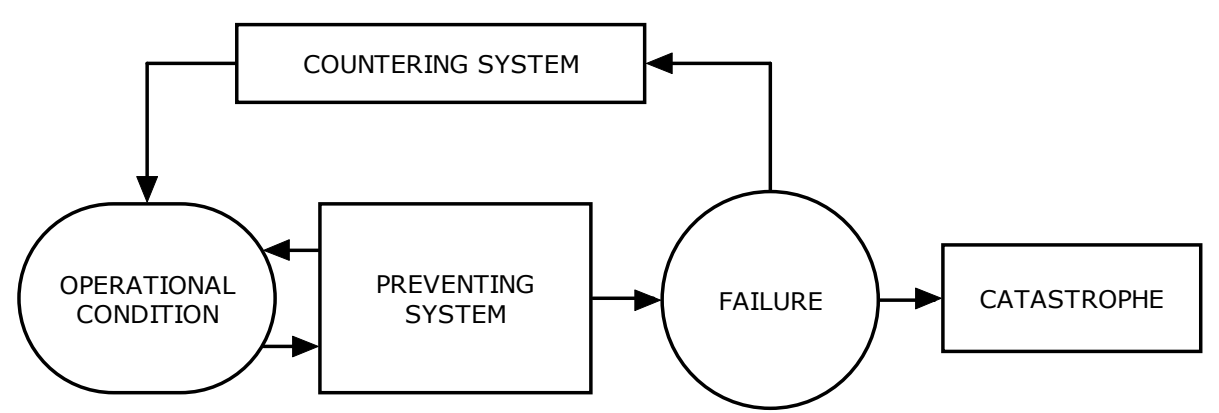

Fig.2. Vessel reliability conditions

Operational condition is a vessel standard service condition, which carries out given task. Failure is condition which extorts nonconventional system operating, technical and functional damage of vessel. Failure is a staging post to catastrophe, but at the same time it is a reversible condition without necessity proceeding to catastrophe. Catastrophe preventing systems consist of technical and organisational protection and acts taken by vessel crew. Catastrophe is a vessel condition causes her operation disabling and doesn't allow to fast reverse to operational condition. Transition from failure to catastrophe condition is defined by probability of consequences exceeded tolerable level in assumed time period: $P_{C}(T)=f\left(c_{i} \geq C_{i}\right)$.

Loss quantity can be represented in monetary units or in "social acceptance level". Human losses are estimated theoretically based on PLL (Potential Loss of Life) factor. In vessel safety analysis ALARP (As Low As Reasonable Practible) factor is used for predict loses [8].

\section{Factors determining vessel safety}

Technical and operational safety vessel assessment is carried out by Classification Societies, governmental institutions and vessel crew members. Classification Societies inspections are review of vessel technical condition and the aim of inspections is restore assumed theoretical safety level. Governmental institutions: Port State Control and Flag State Control inspections the goal is detection differences between existed and desired safety condition.

Real safety assessment is carried out by vessel crew members in reference to actual operational condition. Crew carries out assessment, based on knowledge, information and experience in reference to environmental condition. 
Vessel real safety is estimated by crew in accordance to self safety feeling. In this case, the safety indicator is probability of threat appearing with reference to subjective assessment of vessel technical condition, sea condition and vessel response to environmental forces acts. When the operator feels the danger then he starts conscious acting to avoid it.

Vessel safety indicators analysed by crew are:

- vessel construction condition, visible damages, sounds of working construction,

- vessel list and rolling,

- preventing systems warning signals.

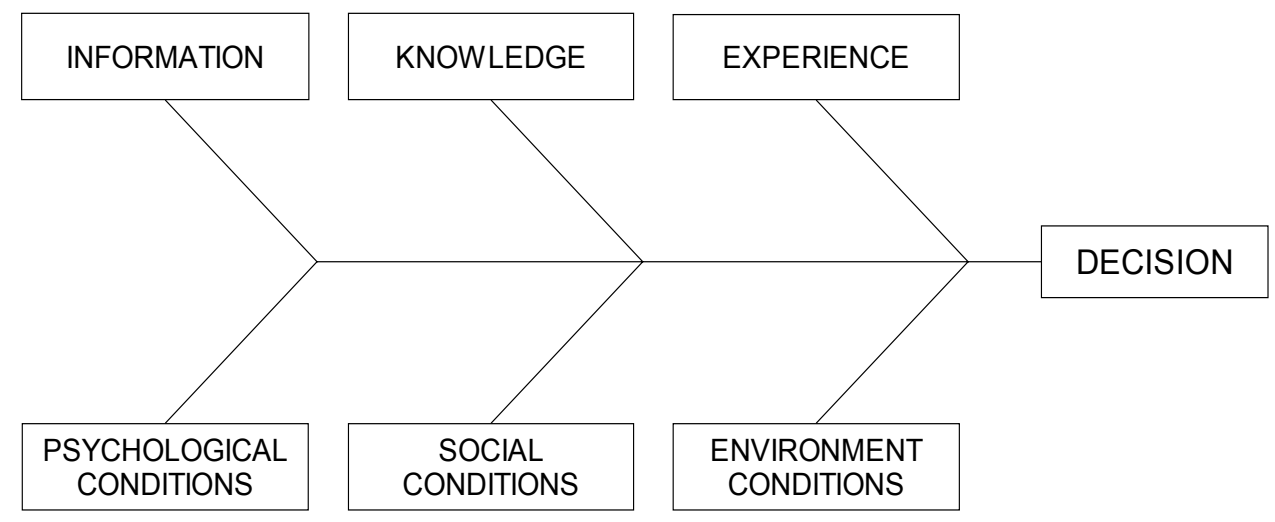

Fig. 3. Decision factors

The integral parts of catastrophe preventing systems is decision making process performed by crew member. Decision making depends on subjective safe feeling.

For requirements of safety analysis, vessel operational conditions are divided into the groups according to possibilities of identification by crew:

○ $\mathrm{C} 1$ - all rules are obeyed, crew works according to recommendation of alert systems, it does not lead to failure or catastrophe

- $\mathrm{C} 2$ - all rules are obeyed, crew works according to recommendation of alerting systems, it leads to failure or catastrophe

○ $\mathrm{C} 3$ - rules, procedures, recommendations are not obeyed but it does not lead to failure or catastrophe

○ $\mathrm{C} 4$ - rules, procedures, recommendations are not obeyed and it leads to failure or catastrophe. 


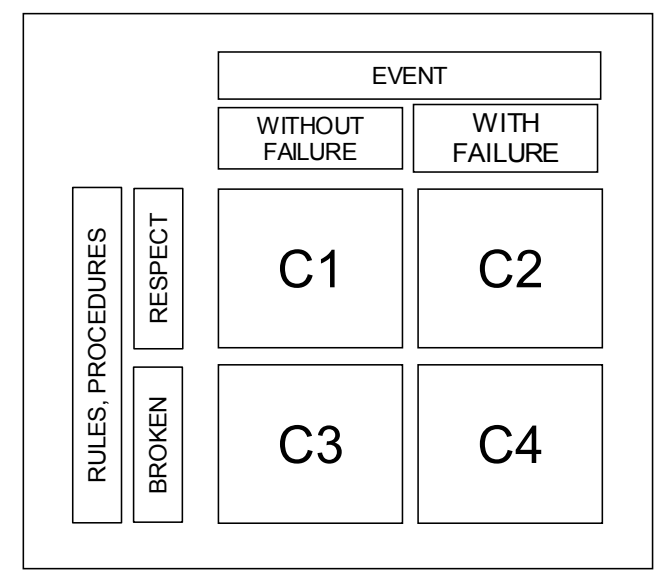

Fig. 4. Threat assessment in reference to system operational work

In case of threat appearing without failure or catastrophe consequences, risk function $R$ reaches zero value and the threat is not recorded (cond. C3) because of broken rules.

Probability of accident $\mathrm{P}_{\mathrm{A}}$ is function of threat conditions, actual technical conditions and crew members acting.

$$
P_{A}=f\left(P_{D}, P_{V V}, P_{O C}\right)
$$

Where $P_{D}$ is the probability of threat, $P_{V V}$ is the probability of susceptibility to threat, it depends on technical condition and psychical condition of crew, $P_{O C}$ is the probability of improper/lack of operators acting [1].

$$
P_{O C}=P_{M} \cdot P_{S S}
$$

Where $P_{M}$ is the probability of operator fault and $\mathrm{P}_{S S}$ is the probability of not taking action for failure or catastrophe preventing due to self safety feeling. Subjective safety is a crew member psychical condition when the danger is not recorded. Subjective safety is disrupted by fatigue and stress. Probability $\mathrm{P}_{\mathrm{SS}}$ of not taking preventing action can be calculated by Bayesian formula. If $\mathrm{S}$ means a level of subjective safety, then $\mathrm{C}$ means that the crew member does not take preventing action. Probability is determined by expression: 


$$
P\left(C_{i} \mid S\right)=\frac{P\left(C_{i}\right) \cdot P\left(S \mid C_{i}\right)}{P(S)}=\frac{P\left(C_{i}\right) \cdot P\left(S \mid C_{i}\right)}{\sum_{j=1}^{n} P\left(C_{j}\right) \cdot P\left(S \mid C_{j}\right)}
$$

Where $P(C)$ is the probability of not taking action by crew member due to knowledge, experience and possibilities, $P(S)$ is the probability of subjective safety level, $P(C \mid S)$ is the probability of not taking action when the operator is in assumed subjective safety level and $P(S \mid C)$ is a probability of remaining in assumed subjective safety level when the operator does not take action, it relates to conditions $\mathrm{C} 1$ and $\mathrm{C} 3$.

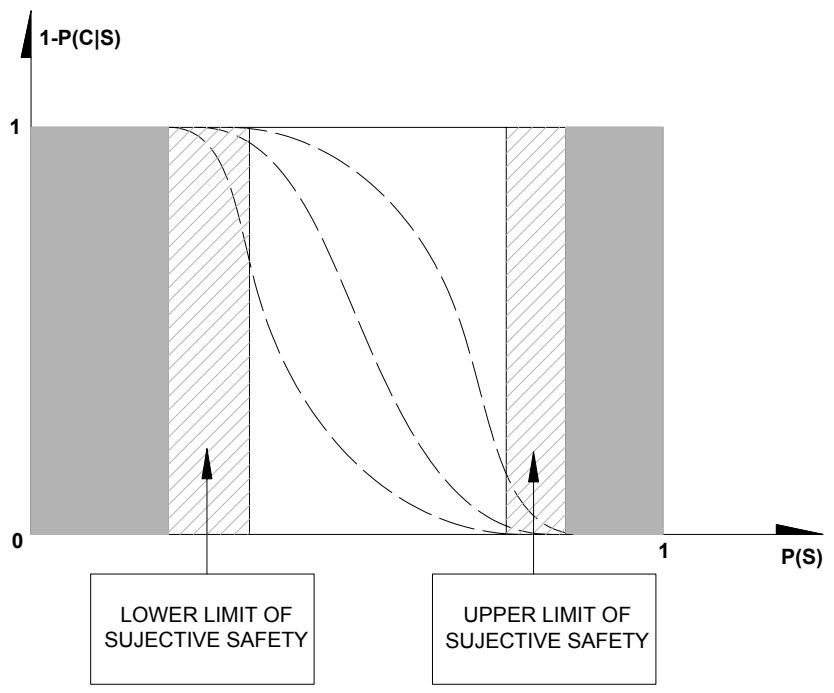

Fig. 5. Probability of operator decision/action making

Rules, operational procedures are preventing systems which protect ship safety. Breaking rules, evading procedures is a safety system failure. Rules supporting vessel safety are treat as not necessary burden, sometimes causing danger for safety.

Reasons of these occurrences are given events:

- All failures are not recorded during vessel operations. Some failures which appear but not caused visible consequences can be not recorded.

- For few years safety procedures have been introduced to vessels. In practice, procedures are subsequent documents which must be filled 
in. Quantity of these documents are arising considerably, crew cannot fill them honestly. Crew members find them as a danger for vessel safety. Then it start unbelief in sense of safety procedures.

- Some parts of rules and safety procedures have mistakes causing danger to crew safety. The reason of this situation is rule/procedure preparing process. Sometimes procedures are unified for all vessels, and the responsible man does not check details and characteristic of the vessel. Procedure mistake makes safety responsible company unbelievable.

- In notable quantity of cases safety procedures, rules and circulars are only form of confirmation of company existing sense. Crew members perceive rules as not working absurd.

\section{Conclusions}

Vessel safety improving process produces problems with implementation experimental data concerning human factor and failures' causes. Reasons of above mentioned are "passive resistance" of crew members, companies' costs and long term putting rules into practice.

Vessel safety assessment carried out upon IMO standards allows theoretical estimating of safety without actual vessel conditions details and condition of crew.

Assessment of actual vessel safety condition is based on crew member's subjective safety idea. Imperative demand taking action by operator involves feeling of threat but it does not include potential consequences of catastrophe. Determining of subjective safety factors as probability of no taking action $P_{S S}$, is necessary to find real vessel safety condition level.

Creating an authoritative safety factors needs implementation principles of safety estimating process into crew members education and training. Actually it goes to beyond existing STCW convention standards.

\section{References}

1. Chavas J.P. „Risk analysis in theory and practice”, Elsevier Inc, London 2004

2. Smith A., Allen P., Wadsworth E.,"Seafarer fatigue: The Cardiff research programme", Cardiff University, 2006 
3. Smolarek L., Soliwoda J.”Analiza niezawodności człowieka w aspekcie bezpieczeństwa statku", TranNav, Szczecin 2007

4. Soliwoda J., „Metody oceny ryzyka i skutków awarii morskich statków handlowych", XXX Zimowa szkoła niezawodności, Szczyrk 2005

5. Soliwoda J.”Ocena bezpieczeństwa konstrukcji oceanotechnicznych podczas eksploatacji", Transport XXI, Stare Jabłonki 2007

6. "Guidance on the use of human element analysing process and formal safety assessment in the IMO rule making process", IMO MSC Circ. 1022, 2002

7. "Human element vision, principles and goals for the organization", IMO Res. A.947(23), 2004

8. "FSA of Bulk Carriers Fore-end Watertight Integrity", IACS 2004, http://www.iacs.org.uk 


\section{CZYNNIKI DETERMINUJĄCE OCENE BEZPIECZEŃSTWA STATKU W TRAKCIE EKSPLOATACJI}

\section{Wprowadzenie}

Przez wiele wieków eksploatacji statków wypracowano metody mające na celu operowanie statkami na założonym poziomie bezpieczeństwa. Do podstawowych sposobów zapewniania bezpieczeństwa statków należały przepisy prawne określające formy i sposoby jego poprawnego eksploatowania. Historycznie tymi przepisami zajmowały się instytucje klasyfikacyjne jako organizacje świadczące usługi oceny stanu technicznego statków. Od połowy XX w przepisy dotyczące wymagań technicznych dotyczących statków, wykształcenia załóg i działań operacyjnych podejmowanych $\mathrm{w}$ celu zapewnienia bezpieczeństwa przygotowywane są również przez Międzynarodową Organizację Morską (IMO) [6].

Obowiązujące dzisiaj przepisy prawne dotyczące bezpieczeństwa statku zakładają standaryzację członka załogi. Standaryzacja ta obejmuje aspekty fizyczne ludzi jak i psychologiczne. Nie uwzględnia się natomiast zróżnicowania wiedzy, doświadczenia, kultury. Skutkuje to znaczną ilością wypadków nieprzewidywanych przez istniejące systemy bezpieczeństwa.

Taki stan bezpieczeństwa jest akceptowany ze względów ekonomicznych. Statki mają jak przewozić jak najwięcej ładunku i jak najwięcej zarabiać Straty o założonym pułapie są więc akceptowane przez firmy ubezpieczające.

\section{Bezpieczeństwo statku}

Statek morski jest złożonym systemem działającym w zmiennych warunkach eksploatacyjnych. Różnorodność przewożonych ładunków, operacje ładunkowe $\mathrm{w}$ różnych portach oraz zmienność warunków meteorologicznych czyni statek obiektem o zmieniającym się wskaźniku bezpieczeństwa.

Bezpieczeństwo statku można analizować jako proces dwuelementowy składający się z: 
- teoretycznego bezpieczeństwa statku - zakładanego bezpieczeństwa, którego miarą jest funkcja ryzyka analizowana w dłuższym okresie czasu w odniesieniu do istniejących ogólnych parametrów systemu.

- rzeczywistego bezpieczeństwa statku - bezpieczeństwa osiaganego w eksploatacji, miara jest funkcja ryzyka analizowana $\mathrm{w}$ odniesieniu do rzeczywistego stanu statku.

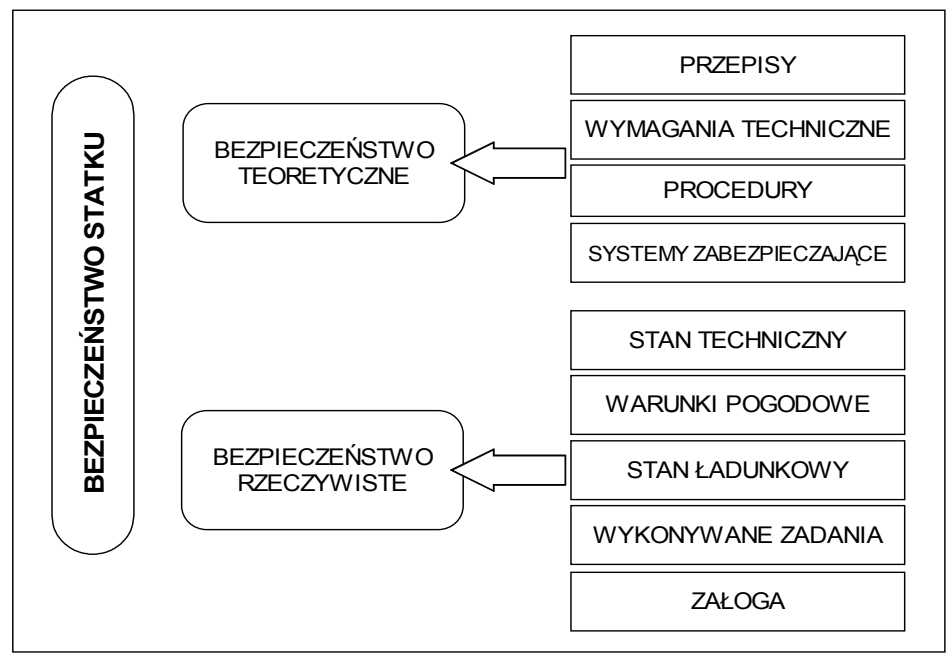

Rys. 1. Bezpieczeństwo statku morskiego

Miarą bezpieczeństwa statku morskiego jest ryzyko zdefiniowane jako funkcja zagrożeń $\mathrm{i}$ strat $\mathrm{w}$ odniesieniu do ryzyka teoretycznego i rzeczywistego.

$$
R=f\left(P_{A}, P_{C}\right)
$$

Gdzie $P_{A}$ oznacza prawdopodobieństwo wystapienia zagrożenia lub awarii systemu, natomiast $P_{C}$ jest prawdopodobieństwem wystapienia strat odpowiedniej kategorii.

Przyczyny awarii statków można podzielić na trzy zasadnicze grupy: warunki hydrometeorologiczne, błędy popełnianie przez operatorów, zużycie i zmęczenie materiału.

Wartości funkcji ryzyka są opracowywane dla standardowych zagrożeń [4]. Uzyskiwane $\mathrm{w}$ ten sposób informacje mogą być nierzetelne, co skutkuje nierzeczywistą wartością funkcji ryzyka. Ocena bezpieczeństwa statku bazująca na standardowych wartościach zagrożeń jest niepraktyczna z punktu widzenia załogi. 


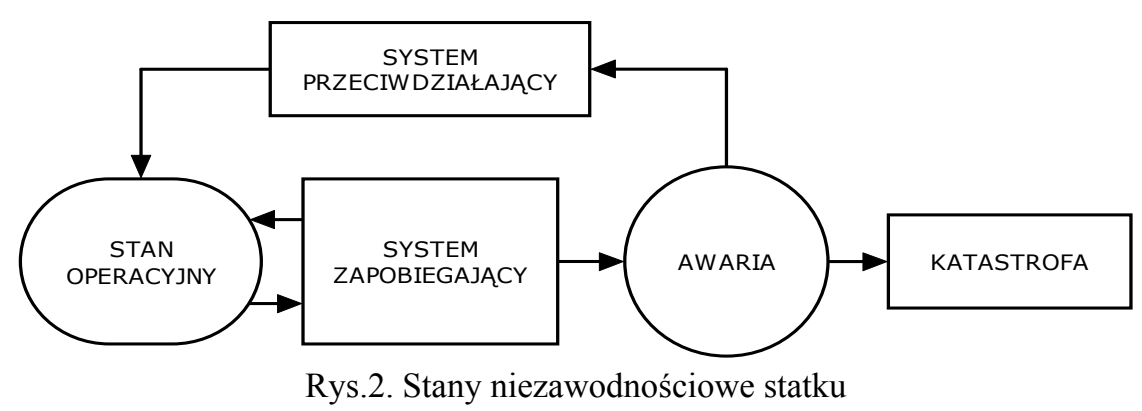

Stan operacyjny jest standardowym stanem eksploatacyjnym jednostki morskiej wykonującej założone zadanie. Awaria jest stanem wymuszającym niestandardowe działanie systemu, uszkodzenie systemu technicznego jak również funkcjonalnego jednostki. Jest to stan pośredni do stanu katastrofy, jednocześnie awaria jest stanem odwracalnym, bez konieczności znalezienia się w stanie katastrofy. System zapobiegający katastrofie składa się z zabezpieczeń technicznych i organizacyjnych oraz działań podejmowanych przez załogę statku. Katastrofa określa natomiast stan awaryjny jednostki, który wymaga wyłączenia jej z eksploatacji oraz nie pozwala na szybki i możliwy powrót do stanu operacyjnego.

Przejście ze stanu awarii do stanu katastrofy jest opisywane prawdopodobieństwem zaistnienia strat przewyższających poziom akceptowalny w założonym okresie czasu: $P_{C}(T)=f\left(c_{i} \geq C_{i}\right)$.

Wielkość strat może być wyrażana w jednostkach „monetarnych” lub „poziomie akceptacji społecznej”. Straty ludzkie są szacowane teoretycznie na podstawie wskaźnika PLL (Potential Lose of Life). W analizach bezpieczeństwa obiektów morskich wprowadza się pojęcie strat akceptowalnych (ALARP - As Low As Resonable Practible)[8].

\section{Czynniki determinujące ocenę bezpieczeństwa statku}

Ocena technicznego oraz operacyjnego bezpieczeństwa statku w eksploatacji jest przeprowadzana przez Towarzystwa Klasyfikacyjne, instytucje rządowe oraz załogę statku. Inspekcje Towarzystw Klasyfikacyjnych są przeglądami istniejącego stanu technicznego statku i ich celem jest przywrócenie statkowi zakładanego poziomu bezpieczeństwa teoretycznego. Przeglądy instytucji rządowych (Port State Control, Flag State Control) mają na celu wykrycie rozbieżności między istniejącym stanem bezpieczeństwa technicznego i operacyjnego a stanem pożądanym. 
Ocena rzeczywistego bezpieczeństwa statków jest przeprowadzana natomiast przez załogę $\mathrm{W}$ odniesieniu do chwilowego stanu eksploatacyjnego. Przeprowadza ona ocenę bezpieczeństwa statku w oparciu o posiadaną wiedzę, ilość i jakość informacji w odniesieniu do warunków zewnętrznych.

Rzeczywiste bezpieczeństwo statku jest oceniane przez jego załogę ze względu na osobiste poczucie bezpieczeństwa. Analizowanymi wskaźnikami bezpieczeństwa są głównie szanse wystąienia zagrożenia w odniesieniu do subiektywnej oceny technicznego stanu statku, stanu morza i odpowiedzi statku na oddziaływania zewnętrzne. W chwili, gdy operator odczuwa zagrożenie podejmuje świadome działanie w celu jego uniknięcia. Wskaźnikami bezpieczeństwa statku analizowanymi przez załogę są:

- stan konstrukcji statku, widoczne uszkodzenia i dźwięki pracującej konstrukcji

- przechyły i kołysania statku,

- sygnały ostrzegawcze podsystemów zabezpieczających.

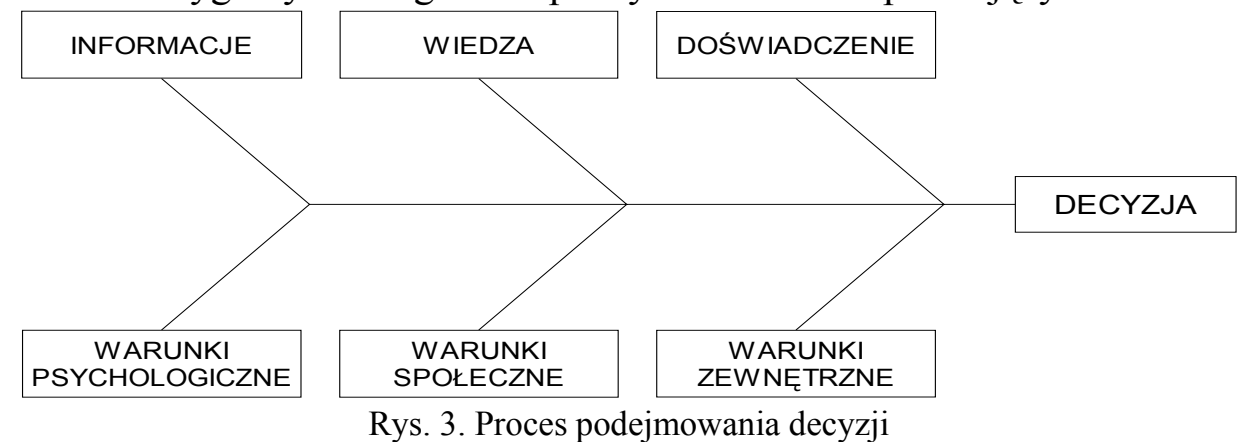

Integralną częścią systemów przeciwdziałających katastrofie jest podejmowanie decyzji przez załogę statku. Podjęcie decyzji jest warunkowane przez subiektywne odczucie zagrożenia.

Dla potrzeb analizy bezpieczeństwa statku podzielono stany eksploatacyjne ze względu na możliwości ich identyfikacji przez załogę:

- C1 - wszelkie przepisy są przestrzegane, załoga postępuje według zaleceń i wskazań systemów ostrzegających, nie dochodzi do awarii lub katastrofy,

○ $\quad$ C2 - wszelkie przepisy są przestrzegane, załoga postępuje według zaleceń i wskazań systemów ostrzegających, dochodzi jednak do awarii lub katastrofy,

○ C3 - przepisy, procedury, wskazania systemów są nieprzestrzegane, jednak nie dochodzi do awarii lub katastrofy, 
○ $\quad$ C4 - przepisy, procedury, wskazania systemów zabezpieczających są nieprzestrzegane i dochodzi do katastrofy.

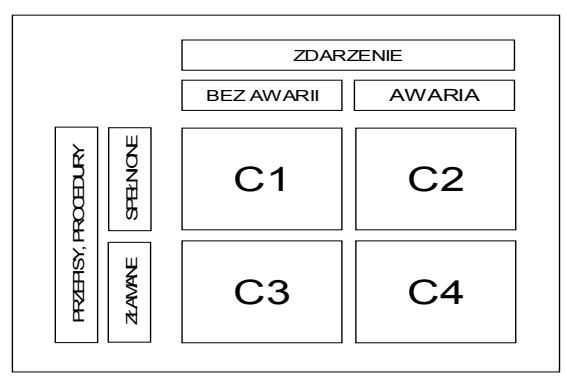

Rys. 4. Ocena stanów zagrożenia w odniesieniu do działania systemu

W przypadku wystapienia zagrożenia bez konsekwencji w postaci awarii lub katastrofy funkcja ryzyka $R$ osiaga wartość zerową (stan C3) i zagrożenie jest to rejestrowane ze względu na złamanie przepisów.

Prawdopodobieństwo wystapienia awarii $P_{A}$ jest funkcją wystąpienia stanów zagrożeń, aktualnego stanu konstrukcji oraz działania operatorów.

$P_{A}=f\left(P_{D}, P_{V V}, P_{O C}\right)$

Gdzie $\mathrm{P}_{\mathrm{D}}$ oznacza prawdopodobieństwo wystąpienia zagrożenia, $\mathrm{P}_{\mathrm{Vv}}$ jest prawdopodobieństwem osiągnięcia przez konstrukcję i załogę statku stanu podatności na zagrożenie, a $\mathrm{P}_{\mathrm{OC}}$ oznacza prawdopodobieństwo nieprawidłowej/braku reakcji operatorów [1].

$$
P_{O C}=P_{M} \cdot P_{S S}
$$

Prawdopodobieństwo $\mathrm{P}_{\mathrm{M}}$ określa szanse popełnienia błędu przez członka załogi, natomiast $P_{\mathrm{SS}}$ - prawdopodobieństwo nie podjęcia działań zapobiegających awarii lub katastrofie ze względu na odczuwanie bezpieczeństwa subiektywnego.

Prawdopodobieństwo $\mathrm{P}_{\mathrm{SS}}(\mathrm{P}(\mathrm{C} \mid \mathrm{S}))$ nie podjęcia działań zapobiegających awarii lub katastrofie można określić korzystając $\mathrm{z}$ twierdzenia Bayesa. Jeśli S oznacza poziom subiektywnego bezpieczeństwa, to $\mathrm{C}$ oznacza, że członek załogi nie podejmie działań korygujących. Prawdopodobieństwo to jest określone wyrażeniem:

$$
P\left(C_{i} \mid S\right)=\frac{P\left(C_{i}\right) \cdot P\left(S \mid C_{i}\right)}{P(S)}=\frac{P\left(C_{i}\right) \cdot P\left(S \mid C_{i}\right)}{\sum_{j=1}^{n} P\left(C_{j}\right) \cdot P\left(S \mid C_{j}\right)}
$$


Gdzie $\mathrm{P}(\mathrm{C})$ jest prawdopodobieństwem nie podjęcia odpowiednich działań przez członka załogi, warunkowane jest ono doświadczeniem, wiedzą i możliwościami działania. $\mathrm{P}(\mathrm{S})$ jest to prawdopodobieństwo znajdowania się $\mathrm{w}$ stanie subiektywnego bezpieczeństwa, $\mathrm{P}(\mathrm{C} \mid \mathrm{S})$ oznacza prawdopodobieństwo nie podjęcia działań jeśli operator znajduje się $\mathrm{W}$ stanie subiektywnego bezpieczeństwa, a $\mathrm{P}(\mathrm{S} \mid \mathrm{C})$ - prawdopodobieństwo pozostawania się w stanie subiektywnego bezpieczeństwa jeśli operator nie podejmuje działań, odnosi się to do stanów C1 i C3.

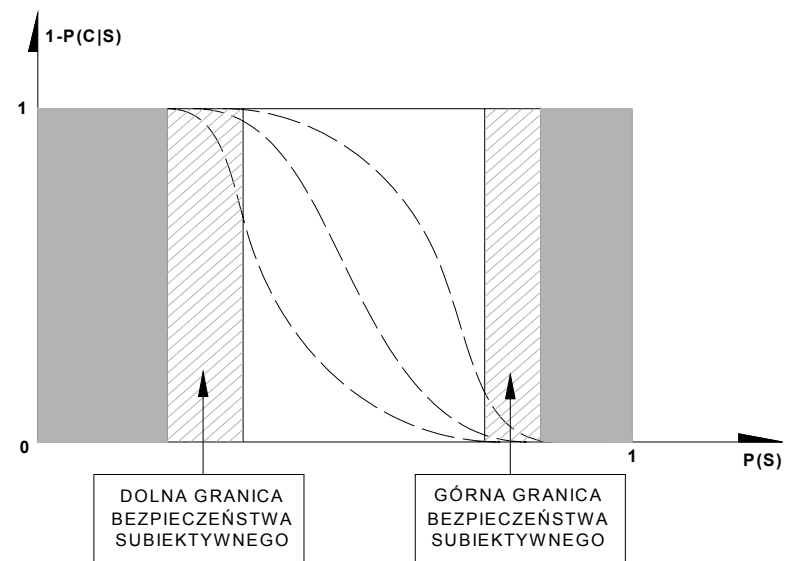

Rys. 5. Prawdopodobieństwo podjęcia działania/decyzji operatora

Bezpieczeństwo subiektywne jest stanem psychicznym w którym członek załogi statku nie odczuwa zagrożenia. Subiektywne poczucie bezpieczeństwa jest zakłócane przez zmęczenie oraz stres.

Przepisy wspomagające bezpieczeństwo statków morskich są traktowane przez załogi statków niejednokrotnie jako przepisy nie zwiększające ich bezpieczeństwa a wręcz jemu zagrażające.

Przyczynami tego zjawiska są następujące zdarzenia:

- Na statkach nie są rejestrowane wszystkie wypadki. Awaria, która zaistniała na statku i nie doprowadziła do strat może być nie zarejestrowana.

- Na statkach wprowadzane są procedury mające na celu zwiększenie bezpieczeństwa statku. W praktyce są to kolejne dokumenty, które załoga statku musi wypełniać. Ilość tych dokumentów wzrosła tak znacznie, że rzetelne ich wprowadzanie jest uznawane przez załogi statków jako zagrażające bezpieczeństwu statku. Stąd pojawia się brak wiary w 
sensowność kolejnych dokumentów i procedur zapewniających bezpieczeństwo.

- Część przepisów oraz procedur obarczona jest błędami, które mogą doprowadzić do katastrofy statku. Przyczyną tego zjawiska jest obowiązek przygotowania procedur zapewniających bezpieczeństwo statku przez firmę zarządzającą statkiem. Błąd procedury jest postrzegany przez załogi statków jako niekompetencja firmy.

- W znacznej części przypadków procedury i przepisy służące zapewnianiu bezpieczeństwa są jedynie formą potwierdzenia sensu istnienia zespołów je tworzących. Przepisy tego rodzaju są postrzegane przez załogi statków jako absurdalne, których nie należy przestrzegać aby w ich pojęciu zapewnić bezpieczeństwo statku.

\section{Podsumowanie}

W procesie poprawy bezpieczeństwa powstaja problemy z implementacja otrzymanych wyników analiz wpływu czynnika ludzkiego w istniejących obiektach eksploatowanych na morzu. Przyczynami tych problemów są: „bierny opór” załóg, koszty obciążające firmę, długoterminowość wprowadzania zaleceń.

Ocena bezpieczeństwa statku przeprowadzana według standardów IMO pozwala na teoretyczną oszacowanie bezpieczeństwa bez szczegółowego uwzględniania aktualnego stanu technicznego statku i wpływu czynnika ludzkiego.

Ocena chwilowego stanu bezpieczeństwa statku bazuje na pojęciu bezpieczeństwa subiektywnego członków załóg. Imperatyw wymagający podjęcia działań przez załogę nie obejmuje samo odczucie zagrożenia natomiast nie uwzględnia ewentualnych skutków katastrofy. Dla określenia rzeczywistego stanu bezpieczeństwa konieczne jest znalezienie parametrów zagrożenia subiektywnego odczuwanego przez załogę statku, i prawdopodobieństwa nie podjęcia działań - $P_{S S}$.

W celu stworzenia miarodajnego zakresu wskaźników bezpieczeństwa teoretycznego i rzeczywistego konieczna jest implementacja zasad oceny do programów nauczania i szkolenia załóg statków morskich wykraczająca poza obecnie obowiązujące standardy Konwencji STCW.

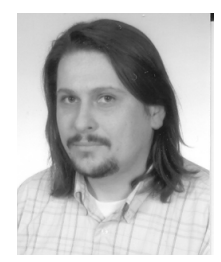

DSc, Eng. SOLIWODA Jaroslaw, Gdynia Maritime University, Ship Operation Dep. specialisation: engineering, reliability, vessel safety, vessel stability. 